\title{
First reports of Cotton leaf curl Gezira virus and Okra yellow crinkle virus associated with okra leaf curl disease in Côte d'Ivoire
}

\author{
K. Séka ${ }^{1,2}$, A. Ouattara ${ }^{3,4}$, K.P. Assiri ${ }^{2}$, K.D. Kra ${ }^{2}$, M. Hoareau ${ }^{1}$, P. Lefeuvre ${ }^{1}$, H. Atta Diallo ${ }^{2}$ and J.M. Lett $^{1 *}$ \\ ${ }^{1}$ CIRAD, UMR PVBMT, Pôle de Protection des Plantes, 97410 Saint-Pierre, lle de La Réunion, France; ${ }^{2}$ Université Nangui \\ Abrogoua, 02 BP 801 Abidjan, Côte d'Ivoire; ${ }^{3}$ Université de Ouagadougou, 03 BP 7021, Ouagadougou 03, Burkina Faso; ${ }^{4}$ \\ INERA, LMI Patho-Bios, 01 BP 476, Ouagadougou 01, Burkina Faso
}

*E-mail: lett@cirad.fr

Received: 02 Jun 2016. Published: 23 Aug 2016.

Okra leaf curl disease (OLCD) is commonly observed in okra (Abelmoschus esculentus) crops in several African countries (N'Guessan et al., 1992). Affected plants are severely stunted with apical leaf curl (upward or downward), distortion and thickening of the veins. In Africa, OLCD is associated with a complex of several strains of two begomovirus species: Cotton leaf curl Gezira virus (CLCuGV; Idris \& Brown, 2002) and Okra yellow crinkle virus (OYCrV; Shih et al., 2007).

In 2012 and 2013, severe symptoms of leaf curling, deformation, and vein thickening (Fig. 1), resembling those of okra leaf curl disease were observed on okra in four localities in south-eastern Côte d'Ivoire (Table 1). Fourteen leaf samples with symptoms were collected and tested for the presence of begomoviruses using a polymerase chain reaction (PCR) assay with a set of degenerate primers designed to amplify the coat protein gene of Old World begomoviruses (Clust4CP-F342, 5'-TATMATCATTTCCACBCCVG-3'; Clust4CP-R1032, 5'-GCATGAGTACATGCCATATAC- ${ }^{\prime}$ ). PCR products of the expected sizes were obtained for nine samples suggesting the presence of Old World monopartite begomoviruses in all four localities (Table 1).

PCR positive samples were further processed and full-length viral genomes were amplified from four samples (Table 1) by rolling-circle amplification, cloned using the BamHI restriction enzyme and sequenced. One complete genome sequence (GenBank Accession No. KX100570) showed the highest pairwise sequence identity of $99 \%$ (100\% coverage) with isolates of the Niger strain of $\mathrm{CLCuGeV}$ from Niger (CLCuGeVNE[NE:Sad:NG2FL:Ok:07], FJ469627) and Burkina Faso (CLCuGeVNE[BF:Kap:Ok4:08], FN554524). The other three sequences (KX100571 to KX100573) showed the highest pairwise sequence identity of $98-99 \%$ (100\% coverage) with isolates of the Mali strain of OYCrV from Mali (OYCrV-ML[ML:Mlo1:04], DQ902715; OYCrV-ML[ML:Bam4:06], EU024119). A maximum likelihood phylogenetic tree, produced from alignments of publicly available begomovirus sequences (MEGA6; Tamura et al., 2013), confirmed the genetic relationship of Ivorian CLCuGeV and $\mathrm{OYCrV}$ isolates with isolates from three neighbouring countries, Burkina Faso, Mali and Niger (Fig. 2).

To our knowledge, this is the first report of $\mathrm{CLCuGeV}$ and $\mathrm{OYCrV}$ implicated in OLCD in Côte d'Ivoire. Our results confirm that OLCD is associated with a complex of several strains of $\mathrm{CLCuGeV}$ and $\mathrm{OYCrV}$ in sub-Saharan Africa (Tiendrebeogo et al., 2010) and show that Ivorian isolates are genetically closely related to strains described in West Africa.

\section{Acknowledgements}

This study was funded by the Région Réunion, the European Union (FEDER) and the CIRAD.

\section{References}

Delatte H, Martin DP, Naze F, Goldbach R, Reynaud B, Peterschmitt M, Lett JM, 2005. South West Indian Ocean islands tomato begomovirus populations represent a new major monopartite begomovirus group. Journal of General Virology 86, 1533-1542. http://dx.doi.org/10.1099/vir.0.80805-0

Idris AM, Brown JK, 2002. Molecular analysis of Cotton leaf curl virusSudan reveals an evolutionary history of recombination. Virus Genes 24, 249-256. http://dx.doi.org/10.1023/A:1015380600089

N'Guessan KP, Fargette D, Fauquet C, Thouvenel JC, 1992. Aspects of the epidemiology of okra leaf curl virus in Côte d'Ivoire. Idris AM, Brown JK, 2002. Tropical Pest Management 38, 122-126.

http://dx.doi.org/10.1080/09670879209371668

Shih SL, Green SK, Tsai WS, Lee LM, Levasseur V, 2007. First report of a distinct begomovirus associated with okra yellow crinkle disease in Mali. Plant Pathology 56, 718. http://dx.doi.org/10.1111/j.1365-3059.2007.01599.x

Tamura K, Stecher G, Peterson D, Filipski A, Kumar S, 2013. MEGA6: Molecular Evolutionary Genetics Analysis Version 6.0. Molecular Biology and Evolution 30, 2725-2729. http://dx.doi.org/10.1093/molbev/mst197

Tiendrébéogo F, Lefeuvre P, Hoareau M, Villemot J, Konaté G, Traoré AS, Barro N, Traoré VS, Reynaud B, Traoré O, Lett JM, 2010. Molecular diversity of Cotton leaf curl Gezira virus isolates and their satellite DNAs associated with okra leaf curl disease in Burkina Faso. Virology Journal 7 , 48. http://dx.doi.org/10.1186/1743-422X-7-48

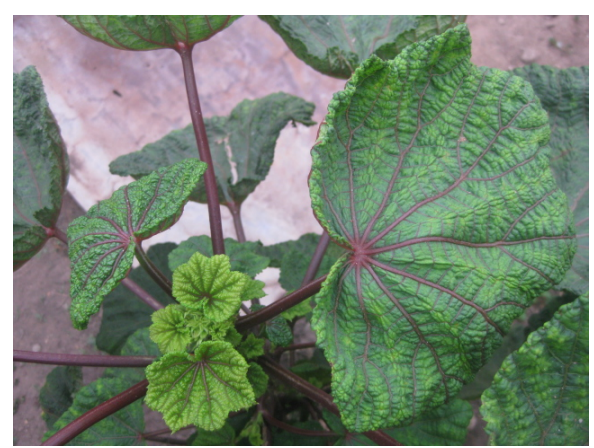

Figure 1

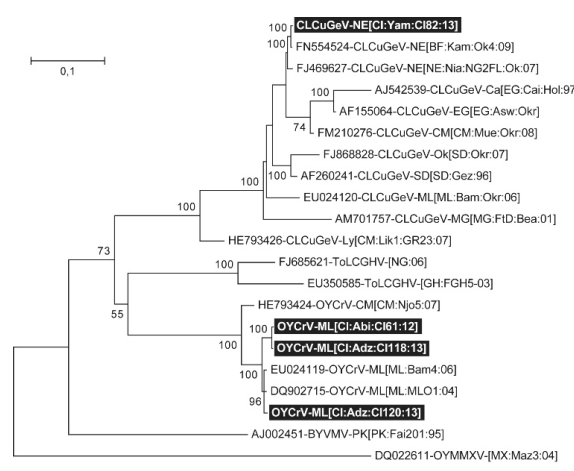

Figure 2

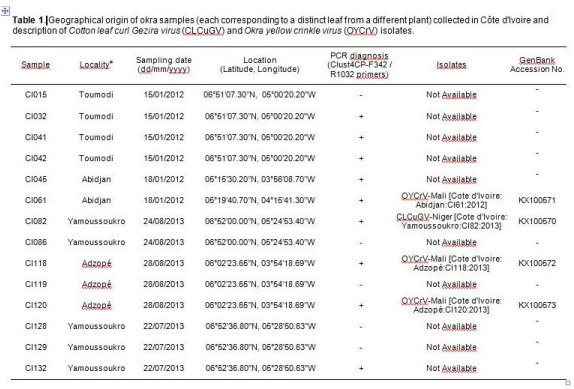

Figure 3

To cite this report: Séka K, Ouattara A, Assiri KP, Kra KD, Hoareau M, Lefeuvre P, Atta Diallo H, Lett JM, 2016. First reports of Cotton leaf curl Gezira virus and Okra yellow crinkle virus associated with okra leaf curl disease in Côte d'Ivoire. New Disease Reports 34, 8. http://dx.doi.org/10.5197/j.2044-0588.2016.034.008 (C) 2016 The Authors

This report was published on-line at www.ndrs.org.uk where high quality versions of the figures can be found.

New Disease Reports is a peer-reviewed on-line journal published by the British Society for Plant Pathology, 